\title{
Pneumomediastinum and subcutaneous emphysema in a rabid bull
}

\author{
Pneumomediastino e enfisema subcutâneo em um bovino com raiva paralítica
}

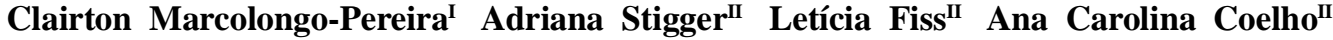 \\ Bianca Santos ${ }^{\text {II }}$ Sergio Vargas Junior ${ }^{\text {II }}$ Ana Lucia Schild ${ }^{\mathrm{I}^{*}}$
}

\section{- NOTE -}

\section{ABSTRACT}

This report describes pneumomediastinum and subcutaneous emphysema in a bull with paralytic rabies. The bull displayed severe swelling in the head, neck, chest and forelimbs extending to the ventrum, including the prepuce, 7 days after the development of neurological signs. At necropsy, extensive subcutaneous emphysema was observed in the neck region, abdominal wall and proximal forelimbs. The lungs failed to collapse and had severe emphysema with bullae. Rabies was suspected due to an ongoing outbreak at the farm and was confirmed by histologic lesions and immunohistochemistry. Similar to humans, pneumomediastinum and subcutaneous emphysema should be considered as an unusual complication of rabies in cattle.

Key words: pneumomediastinum, emphysema, rabies, cattle.

\section{RESUMO}

Descreve-se um caso de pneumomediastino e enfisema subcutâneo em um touro. O animal apresentava edema acentuado na cabeça, no pescoço, no peito e nos membros anteriores, que se estendia pela região ventral do corpo até o prepúcio, após sete dias de sinais neurológicos. Na necropsia, observou-se enfisema subcutâneo na região da cabeça e pescoço, no abdômen e na região proximal dos membros anteriores. O pulmão apresentava enfisema alveolar e formação de bolhas de ar nos lobos. Devido à ocorrência de raiva na propriedade a suspeita inicial foi de raiva, que foi confirmada pelas lesões histológicas e pela imunohistoquímica. Pneumomediastino e enfisema subcutâneo devem ser considerados como uma complicação incomum de raiva em bovinos, similar à mencionada em seres humanos.

Palavras-chave: pneumomediastino, enfisema, raiva, bovino.
Pneumomediastinum is a condition characterized by presence of free air in the mediastinum (BROCKMAN \& PUERTO, 2004). In cattle, the condition is most common in cows after calving, due either to exacerbation of preexisting chronic pulmonary disease or as a result of exertion during parturition (DIVERS, 2007). It has also been described as a complication of bronchopneumonia in cattle (BEZEK et al., 1995). In horses it can be a sequel to trauma (HASSEL, 2007), and in cats it is associated with feline pulmonary herpes virus infection, anesthesia and tracheal tear or rupture (MAES et al., 2011). In humans, pneumomediastinum is a consequence of a wide variety of causes, including esophageal, tracheal, bronchial or alveolar trauma (BANKI et al., 2013); inflammation; or neoplasia (MAES et al., 2011). Cases have also been reported wherein pneumomediastinum is a consequence of pneumonia due to infection by Staphylococcus spp. (ROSHAN et al., 2003), Mycoplasma pneumoniae (FEARON et al., 2007),Pneumocystisjiroveci (former P. carinii) (MOSS et al., 1995; LEE et al., 2009). On rare occasions, idiopathic pneumomediastinum has been associated with paralytic rabies in people (OMEZZINE et al., 1994; KIETDUMRONGWONG \& HEMACHUDHA, 2005; WANG et al., 2013). Idiopathic pneumomediastinum is considered to occur when no specific pathophysiological mechanism can be identified. This report describes pneumomediastinum with subcutaneous emphysema in a bull with paralytic rabies.

\footnotetext{
${ }^{1}$ Laboratório Regional de Diagnóstico, Faculdade de Veterinária (FV), Universidade Federal de Pelotas (UFPel), Campus Universitário, s/n, 96010-900, Pelotas, RS, Brasil. E-mail: alschild@ terra.com.br. *Corresponding author.

IPós-graduação em Medicina Veterinária, FV, UFPel, Pelotas, RS, Brasil.
} 
A 2-year-old Hereford bull showed hindlimb paresis and incoordination over a period of 10 days. Seven days after the onset of the clinical signs, the bull was found recumbent, unable to rise, and displaying stertorous breathing. The bull developed severe subcutaneous emphysema with swelling of the head, neck, (Figure 1A), chest, forelimbs and ventrum producing a crackling sensation. The bull was euthanized, and necropsy was performed immediately after death. Three animals had died recently on the farm after developing neurological signs.

During necropsy, extensive subcutaneous emphysema was observed in the neck, abdominal wall and proximal areas of the forelimbs. The lungs failed to collapse and had severe emphysema with bullae (Figure 1B). The emphysema extended along the aorta and involved the pericardial sac. Gas-filled bullae were on the surface of the liver and in the spleen.
Histopathology examination revealed extensive pulmonary emphysema. There was locally extensive nonsuppurative encephalitis in brain stem, with diffuse lymphocytic perivascular cuffing and multifocal gliosis (Figure 1C). Intracytoplasmic eosinophilic inclusions (Negri bodies) were observed in neurons of the medulla oblongata. No lesions were observed in the other organs. Rabies virus antigen was detected in the Purkinje neurons, spinal cord and obex (Figure 1D) using a goat anti-rabies polyclonal reagent (Chemicon \#5199) according to the technique described by STEIN et al. (2010).

This case highlights the occurrence of pneumomediastinum in a case of paralytic rabies in a bull during an outbreak of the disease in southern Brazil. A similar condition has been described in humans affected by the paralytic form of rabies (KIETDUMRONGWONG \& HEMACHUDHA,

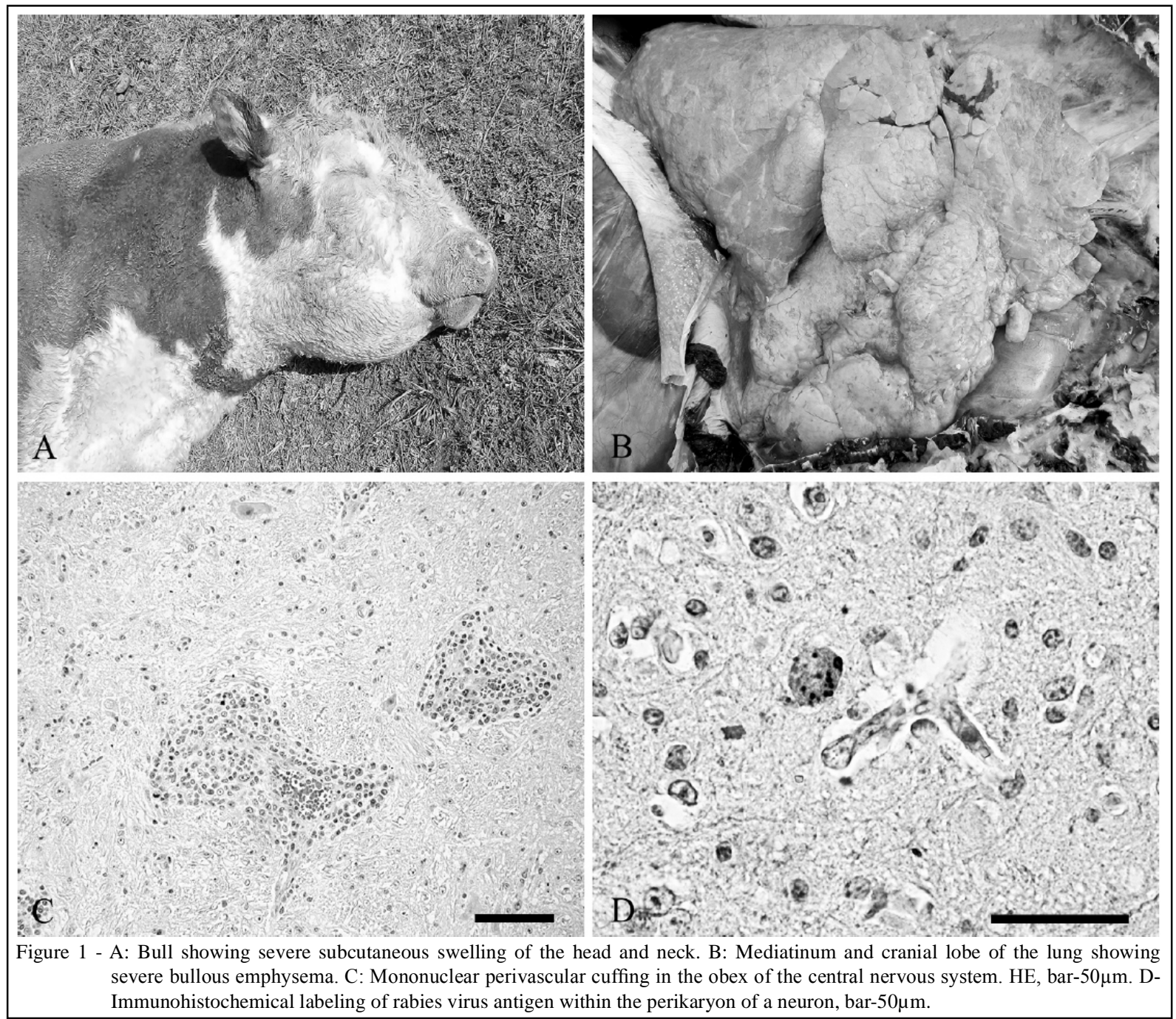

Ciência Rural, v.45, n.1, jan, 2015. 
2005). In the present case, the bull exhibited clinical signs of paralytic rabies over a 7-day period, but the signs were neglected by the farm veterinarian given the uncommon generalized subcutaneous emphysema. In humans, air in the retropharyngeal space and pneumomediastinum can lead to diagnostic misinterpretations, primarily due to the omission of parts of the medical history and symptoms suggestive of rabies (KIETDUMRONGWONG \& HEMACHUDHA, 2005).

The mechanism of pneumomediastinum is unknown; it might be associated with violent spasms of the pharynx and larynx that cause an acute and temporary obstruction of the airways, leading to alveolar rupture under a brief period of increased pressure (WANG et al., 2013). In cattle, subcutaneous and pulmonary emphysema has been attributed to bellowing in cases of rabies in Southern Africa (SWANEPOEL, 1994), probably due to respiratory effort. However, in the present case, the bull had no bellowing history. Pneumomediastinum can also be caused by sharp penetrating trauma to the neck (MAES et al., 2011). In the present case, close inspection at necropsy did not reveal any perforating trauma. Most likely, the pneumomediastinum and subcutaneous emphysema resulted from pulmonary alveolar rupture as a consequence of pharyngeal and/ or laryngeal spasms given that the bull experienced severe respiratory difficulty. In humans, the mechanism of spontaneous pneumomediastinum and subcutaneous emphysema is unclear (WANG et al., 2013). Nevertheless, it has been suggested that uncontrolled pharynx and larynx spasms results in acute and transient obstruction of the airway and esophagus lumen that causes alveolar rupture under transient higher pressure, thereby permitting air to spread elsewhere (MAUNDER et al., 1984).

Acute bovine pulmonary edema and emphysema (fog fever) and intoxication by moldy sweet potatoes contaminated with Fusarium solani can cause pulmonary and subcutaneous emphysema (LÓPEZ, 2012). In the present report, the bull did not graze lush pastures or receive moldy sweet potatoes.

In conclusion, pneumomediastinum and subcutaneous emphysema should be considered an unusual complication of rabies in cattle similar to the presentation described in humans (OMEZZINE et al., 1994). The possibility of rabies infection in cases of severe subcutaneous emphysema and pneumomediastinum should be considered, particularly in the presence of concomitant neurological signs.

\section{ACKNOWLEDGEMENTS}

To Conselho Nacional de Desenvolvimento Científico e Tecnológico $(\mathrm{CNPq})$, for productivity scholarship of Ana Lucia Schild (grant no. 304332/2012-7) and post doctoral scholarship of Clairton Marcolongo-Pereira (grant no. 150246/2014-5).

\section{REFERENCES}

BANKI, F. et al. Pneumomediastinum: etiology and a guide to diagnosis and treatment. American Journal of Surgery, v.206, n.6, p.1001-1006, 2013. Available from: <http://www.sciencedirect. com/science/article/pii/S0002961013004819>. Accessed: Apr. 29, 2014. doi: http://dx.doi.org/10.1016/j.amjsurg.2013.08.009.

BEZEK, D. et al. Bronchopneumonia with unilateral pneumothorax, pneumomediastinum, and pulmonary bullae. Journal of the American Veterinary Medical Association, v.206, p.955-956, 1995.

BROCKMAN, D.J.; PUERTO, D.A. Pneumomediastinum and pneumothorax. In: KING, L.G. (Ed.). Respiratory disease in dogs and cats. St. Louis, Missouri: Saunders, 2004. p.616-624.

DIVERS, T.J. Respiratory diseases. In: DIVERS, T.J.; PEEK, S.P. (Eds.). Rebhun's diseases of dairy cattle. 2.ed. St. Louis: Saunders, 2007. p.79-129.

FEARON, D. et al. Mycoplasma pneumoniae infection complicated by pneumomediastinum and severe mucositis. Journal of Pediatrics and Child Health, v.43, n.5, p.403405, 2007. Available from: <http://onlinelibrary.wiley.com/ doi/10.1111/j.1440-1754.2007.01088.x/pdf >. Accessed: Apr. 29, 2014. doi: 10.1111/j.1440-1754.2007.01088.x.

HASSEL, D.M. Thoracic trauma in horses. Veterinary Clinics of North America: Equine Practice, v.23, p.67-80, 2007. Available from: <http://linkinghub.elsevier.com/retrieve/pii/ S0749073906000873>. Accessed: Jan. 30, 2014. doi: http:// dx.doi.org/10.1016/j.cveq.2006.11.006.

KIETDUMRONGWONG, P.; HEMACHUDHA, T. Pneumomediastinum as initial presentation of paralytic rabies: a case report. BMC Infectious Diseases, v.5, p.92, 2005. Available from: <http://www.biomedcentral.com/1471-2334/5/92>. Accessed: Jan. 30, 2014. doi: 10.1186/1471-2334-5-92.

LEE, J.C. et al. Pneumocystis jiroveci pneumonia and pneumomediastinum in an anti-TNFalpha naive patient with ulcerative colitis. World Journal of Gastroenterology, v.15, n.15, p.1897-1900, 2009. Available from: <http://www.wjgnet. com/1007-9327/pdf/v15/i15/1897.pdf>. Accessed: Apr. 29, 2014. doi: $10.3748 /$ wjg.15.1897.

LÓPEZ, A. Respiratory system, mediastinum, and pleurae. In: McGAVIN, M.D.; ZACHARY, J.F. (Eds.). Pathologic basis of veterinary disease. 5.ed. St. Louis: Elsevier, 2012. p.458-538.

MAES, S. et al. Pneumomediastinum and subcutaneous emphysema in a cat associated with necrotizing bronchopneumonia caused by feline herpesvirus-1. Canadian Veterinary Journal, v.52, p.1119-1122, 2011. Available from: <http://www.ncbi. nlm.nih.gov/pmc/articles/PMC3174511/pdf/cvj_10_1119.pdf>. Accessed: Jan. 28, 2014. 
MAUNDER, R.J. et al. Subcutaneous and mediastinal emphysema. Pathophysiology, diagnosis, and management. Archives of internal medicine, v.144, n.7, p.1447-1453, 1984.

MOSS, S. et al. Pneumocystis carinii pneumonia presenting with pneumomediastinum in an HIV-positive patient. Postgraduate MedicalJournal, v.71,n.837,p.96-97,1995. Availablefrom: <http:// pmj.bmj.com/content/71/832/96.long>. Accessed: Apr. 29, 2014.

OMEZZINE, A. et al. Spontaneous pneumomediastinum: an exceptional complication of rabies. Clinical Infectious Disseases, v.18, p.663-664, 1994. Available from: <http://cid.oxfordjournals. org/content/18/4/662.2.extract $>$. Accessed: Jan. 30, 2014. doi: 10.1093/clinids/18.4.663.

ROSHAN, M. et al. Pneumomediastinum and pneumopericardium in staphylococcalbronchopneumonia. Journal of theAssociation of
Physicians of India, v.51,p.884,2003. Available from: <http://www. japi.org/september2003/PC-884.pdf $>$. Accessed: Apr. 29, 2014

SWANEPOEL, R. Rabies. In: COETZER, J.A.W. et al. (Ed.). Infectious diseases of livestock with special reference to Southern Africa. Cape Town: Oxford University, 1994. p.1123-1182.

STEIN, L.T. et al. Immunohistochemical study of rabies virus within the central nervous system of domestic and wildlife species. Veterinary Pathology, v.47, n.4, p.630-633, 2010. Available from: <http://vet.sagepub.com/content/47/4/630.full.pdf+html>. Acessed: Apr. 29, 2014. doi: 10.1177/0300985810370013.

WANG, W. et al. Spontaneous pneumomediastinum due to paralytic rabies. Brazilian Journal of Infectious Diseases, v.17, p.94-96, 2013. Available from: <http://www.scielo.br/scielo.php ?pid=S141386702013000100016\&script $=$ sci_arttext $>$. Accessed: jan. 30, 2014. doi: http://dx.doi.org/10.1016/j.bjid.2012.04.003. 